\title{
The Influence of Alcohol Outlets on Urban Trauma: A Pilot Study for Geospatial Modeling at a Fine Scale
}

\author{
${ }^{1}$ Max N Brondfield, ${ }^{2}$ Stanley Sciortino, ${ }^{3}$ Catherine Juillard, ${ }^{4}$ Paula Fleisher, ${ }^{5}$ Laura A Schmidt, ${ }^{6}$ Rochelle Dicker
}

\section{RESUMEN}

Antecedentes: La asociación entre la disponibilidad de alcohol y una lesión es desconocida. Nuestro estudio piloto pretende modelar las tasas de trauma a nivel individual y tracto censal para mejor comprender el papel de los puntos de venta de alcohol (AO) en relación con los factores socioeconómicos pensado en influir las lesiones. La correlación de la disponibilidad de alcohol y lesiones en un modelo multinivel puede informar mejor las medidas de política para evitar el trauma y crear un entorno urbano más seguro.

Diseño del estudio: Los traumas entre enero-abril de 2013 (300 lesiones) de un centro de trauma de nivel 1 urbano se analizaron, con respecto a la puntuación de gravedad de la lesión (ISS) y nivel de alcohol en la sangre (BAL). Eventos de lesiones y datos de $\mathrm{AO}$ adquiridos del Control de Bebidas Alcohólicas del Estado se proyectaron sobre un mapa de secciones censales, que incluían datos socioeconómicos y demográficos de la Oficina del Censo de EE.UU. (20092013). Traumas fueron estratificados de acuerdo a la edad, la intencionalidad, y el nivel de alcohol en la sangre. Se llevó a cabo regresiones mínimas cuadradas ordinarias para entender las contribuciones relativas de $\mathrm{AO}$, otras variables dependientes, y auto correlación espacial.

Resultados: Nivel de alcohol en la sangre positivos se asociaron con un mayor ISS entre las víctimas de trauma. A nivel de sección censal, la densidad de fuera de la venta AO per cápita era la variable correlacionada más fuerte con todos los traumas (Rt $2=0,52, p<0,01$ ) y aquellos para los que BAL fue elevado en la admisión (Rt $2=0,74, p<0,01$ ). Los traumatismos violentos mostrarón la asociación más fuerte con el AO-venta per cápita (Rvt $2=0,17$ ). Sin embargo, los niveles de auto correlación espacial eran demasiados altos para validar los resultados del modelo. Las variables socioeconómicas eran insignificantes.

\section{${ }^{1}$ Medical Student, ${ }^{2}$ Chief, ${ }^{3}$ Assistant Professor, ${ }^{4}$ Navigator ${ }^{5,6}$ Professor \\ ${ }^{1,5}$ Department of Student, School of Medicine, University of California,San Francisco, San Francisco, California, USA \\ ${ }^{2}$ Department of Public Health, Genetic Disease Screening and Prevention Branch, San Francisco, California, USA \\ ${ }^{3}$ Department of Surgery, University of California, San Francisco, California, USA \\ ${ }^{4,6}$ Clinical \& Translational Science Institute University of California, San Francisco, San Francisco, California, USA}

Corresponding Author: Max N Brondfield, Medical Student School of Medicine, University of California, San Francisco San Francisco, California, USA, Phone: +14156407279 e-mail: max.brondfield@ucsf.edu
Conclusión: A pesar de la extensa auto correlación censal, modelado preliminar de un traumatismo muestra una promesa significativa para mejor comprender los factores predictivos geoespaciales de estos eventos. Si bien los efectos del alcohol sobre el trauma han sido previstos, en el análisis espacial anterior, esto representa un enfoque piloto más sólido a través de medidas directas de BAL que puede informar mejor la comprensión de predictores espaciales para trauma.

Palabras clave: Toma de alcohol, Nivel de alcohol en sangre, Niveles múltiples modelado, Análisis espacial, Trauma.

How to cite this article: Brondfield MN, Sciortino S, Juillard C, Fleisher P, Schmidt LA, Dicker R. The Influence of Alcohol Outlets on Urban Trauma: A Pilot Study for Geospatial Modeling at a Fine Scale. Panam J Trauma Crit Care Emerg Surg 2016;5(1):1-10.

Source of support: This publication was supported by the National Center for Advancing Translational Sciences, National Institutes of Health, through UCSF-CTSI Grant Number UL1 TR000004. Its contents are solely the responsibility of the authors and do not necessarily represent the official views of the $\mathrm{NIH}$.

Conflict of interest: None.

\section{ABSTRACT}

Background: The association between alcohol availability and injury is known. Our pilot study seeks to model rates of trauma at the individual and census tract level to better understand the role of alcohol outlets (AOs) relative to socioeconomic factors thought to influence injury. Correlating alcohol availability and injury in a multilevel model may better inform policy measures to prevent trauma and create a safer urban environment.

Study design: Traumas in January-April 2013 (300 injury events) from an urban level 1 trauma center were analyzed with regard to injury severity score and blood alcohol level. Injury events and $\mathrm{AO}$ data acquired from the state Alcoholic Beverage Control were projected onto a map of census tracts, which included socioeconomic and demographic data from the U.S. Census Bureau (2009-2013). Traumas were stratified according to age, intentionality, and BAL screening. Ordinary least squares regression was performed to understand the relative contributions of $\mathrm{AO}$, other dependent variables, and spatial autocorrelation.

Results: Positive BAL screens were associated with higher ISS among trauma victims. At the census tract level, density of off-sale $\mathrm{AO}$ per capita was the strongest correlated variable with all traumas $\left(R_{t}{ }^{2}=0.52, p<0.01\right)$ and those for which $B A L$ was elevated on admission $\left(R_{t}{ }^{2}=0.74, p<0.01\right)$. Violent trauma showed the strongest association with on-sale $\mathrm{AO}$ per capita $\left(R_{v t}{ }^{2}=0.17\right)$. However, levels of spatial autocorrelation were

Paper presented in Student Research Competition at the Annual Congress of Panamerican Trauma Society, Santa Cruz, Bolivia, November 2015 
too high to validate model results. Socioeconomic variables were not significant.

Conclusion: Despite extensive autocorrelation among census tracts, preliminary modeling of trauma shows significant promise in better understanding the geospatial predictors of these events. While the influence of alcohol on trauma has been presumed in previous spatial analysis, this pilot represents a more robust approach through direct measures of BAL that can better inform understanding of spatial predictors for trauma.

Keywords: Alcohol outlet, Blood alcohol level, Multilevel modeling, Spatial analysis, Trauma.

\section{INTRODUCTION}

The relationship between alcohol use and traumatic injury is well established. ${ }^{1,2}$ The association between areas in which alcohol can be purchased (e.g., liquor stores) or consumed (e.g., bars and restaurants) and elevated rates of unintentional injury, violent crimes, and suicide, has consistently been demonstrated at the individual level and through spatial analysis. ${ }^{3-9}$ The majority of spatial analysis regarding alcohol outlets and injury has focused on violent crime. With the advent of mapping software, the connection between alcohol and violence has become apparent at a small spatial scale, from cities and counties down to zip codes and neighborhoods. ${ }^{6,9-14}$ Moreover, the influence of alcohol availability on violence has been demonstrated in longitudinal analyses over extended periods of time. ${ }^{8,15}$ The substantial body of literature demonstrating the spatial relationship between alcohol outlet density and trauma (particularly off-sale outlets and violence) leaves little doubt that alcohol availability has an impact on injury rates.

Despite these reports, a number of challenges have limited these analyses. Whereas crime data accessed from police department or government registries can reliably locate incidents, trauma locations are rarely publicly available. Previous spatial analyses focused on trauma have used hospital discharge records that lack documentation of where a trauma occurred, which has resulted in assigning injuries to a patient's zip code of residence instead of event location. ${ }^{4,8,16}$ With regard to the involvement of alcohol in a specific injury, spatial analysis has often relied on aggregated data to serve as a proxy for individual behavior, presuming alcohol use among trauma victims based on time of day or alcohol expenditures. ${ }^{3,4,17}$

In order to more definitively characterize the role of alcohol consumption in trauma, other studies have addressed injury at the level of the individual, analyzing serum alcohol and toxicology data from patient admissions. ${ }^{18-21}$ This work has demonstrated higher odds ratios of trauma among those with elevated blood alcohol level upon hospital admission, particularly for head and facial trauma. Madan et al found that $80 \%$ of assault victims and $63 \%$ of those in motor-vehicle accidents admitted to a level 1 U.S. trauma center had positive serum ethanol screens, although this study found no significant difference in injury severity score (ISS), length of stay, or mortality between groups with positive and negative screens.

Despite the significant amount of spatial analysis and individual-level research involving alcohol and trauma, no previous studies have sought to combine these methodologies with regard to alcohol involvement. Goldstick et $\mathrm{al}^{22}$ recently presented a spatial analysis that included demographics of assault victims to analyze subpopulations, but this work did not contain clinical data (e.g., BAL and drug screens). A multilevel modeling approach, in which individual clinical data regarding alcohol use could be mapped to support spatial analysis, would help resolve a number of the assumptions limiting previous work.

San Francisco, California has the highest off-sale alcohol consumption per capita in the state. ${ }^{23}$ As an urban environment with a single level 1 trauma center, it also represents an ideal catchment area for evaluating traumas in the context of environmental influence. In 2013, San Francisco General Hospital adopted a policy of screening all highest level activation trauma patients for BAL upon arrival in the ED, allowing for the direct evaluation of alcohol use among victims. Additionally, when San Francisco prehospital care providers are dispatched to an incident, they submit run sheets that include the trauma location - a presumably more accurate geographic portrayal than zip codes of residence, considering that many urban injuries occur outside of one's residential area. By leveraging these individual-level data and utilizing spatial analysis, we designed a pilot study to further characterize the relationship between violent injury and alcohol. Unlike previous work, which has either focused only on individual patients or aggregated trauma data without the underlying clinical information, our approach allows for multilevel modeling that can more definitively characterize the role of alcohol (through BAL measures) and geographic predictors in urban trauma. The goal of our study is to pilot this novel modeling methodology for a small subset of injury data in a manner that is reproducible in many urban settings. To our knowledge, this methodology has not been previously reported.

\section{METHODS OF RESEARCH}

\section{Data Sources}

Each "900" (higher acuity) and "911" (lower acuity) trauma patient at San Francisco General Hospital is logged in the institutional Trauma Registry. The electronic registry includes patient information pertaining to the course of clinical care following a traumatic incident. In order to accurately geocode traumas, an incident could only be included if documentation from a prehospital 
care run sheet was included in the patient's chart. Thus, all traumas for which an ambulance was not dispatched or a run sheet was absent from the chart were excluded from this analysis. We requested charts of 1,000 incidents (either 900 or 911) from January-April 2013, which yielded 300 instances for which a trauma address could be determined. These incidents were geocoded based on the reported location of ambulance pickup (often the nearest intersection) and matched with trauma registry data. Incidents were mapped by converting street addresses to latitude and longitude coordinates (in decimal degrees) using Google Maps and subsequently plotting all incidents using ArcGIS software. ${ }^{24}$ Trauma registry data extracted for each incident included patient demographics, time of admission, BAL on admission if tested, E codes with detailed injury description, ISS, and length of hospital stay. Traumas were characterized as "violent", "intentional", or "unintentional" based on E codes. Violent traumas were defined as assault by any mechanism including both penetrating and blunt instruments. Intentional traumas included all violent incidents as well as suicide attempts, while unintentional trauma represented all other injuries.

On-sale (bars, restaurants, etc) and off-sale (corner stores, super markets, etc) alcohol outlet information was acquired from the California Alcoholic Beverage Control (ABC), which maintains up-to-date licensing information for all active liquor licenses in a county. ${ }^{25}$ The database provided by ABC includes a site address, license type, and issue/expiration dates. Within San Francisco County, there were 3661 (2850 on-sale, 811 off-sale) licenses active as of March 2013. Numbers of alcohol outlets by census tract were tabulated for both types of establishments.

The census tract layer $(n=197)$ was provided by San Francisco Enterprise GIS. ${ }^{26}$ Two of these census tracts were entirely non residential and were thus removed from the analysis, leaving a spatial layer with 195 tracts. All demographic data were extracted from the U.S. Census Bureau web site and matched to the census tracts given by SFGIS. ${ }^{27}$ These data included population (with age and racial demographics) as well as housing, poverty, unemployment, and income statistics from the American Community Survey (ACS) 5-year estimates for 2009-2013. Variables chosen for modeling were median income (US\$), individual poverty in the past 12 months $(\%)$, proportion of households led by single female providers (\%), proportion of non-White population (\%), and unemployment rate (\%).

\section{Modeling}

We adopted a preliminary modeling approach to analyze the trauma cohort both as individual incidents and in aggregate at the census-tract level. Factors such as patient age, time of day, substance use indicators, and type of trauma were grouped to form categorical variables for analysis of variance (ANOVA). Time of day was treated as a categorical variable, with an expanded "late-night" bin to include 8pm-6am, as has been done previously., ANOVA models were used to assess characteristics of the traumas at the individual level, specifically whether ISS and BAL varied among subgroups of traumas. Linear regressions were also employed to compare the continuous variables (ISS, BAL, and length of hospital stay) with each other. Analysis was done using SAS and R software. ${ }^{28,29}$

All spatial variables were analyzed at the census tract level using ArcGIS. Alcohol outlets and traumas were aggregated within each tract and normalized on a percapita basis to control for population density. One census tract, San Francisco's Golden Gate Park, represented an alternative land-use area with abnormal population characteristics. While traumas recorded in the park were included in overall analysis, this census tract was removed from spatial models as an outlier, consistent with previous work. ${ }^{4}$ Ordinary least squares (OLSs) regressions explored relationships between the independent variable, trauma density, and numerous socioeconomic indicators, along with alcohol outlet density. Ordinary least squares models were evaluated for multicollinearity (redundancy of variables) and spatial autocorrelation. Spatial autocorrelation, the tendency for neighboring locations to share characteristics, can undermine independence among observations and bias model results. The issue of spatial autocorrelation when using OLS models has been discussed extensively in previous studies. ${ }^{7,13,30}$ Attempts have been made to address autocorrelation in three ways: (1) Assessing the extent of autocorrelation within OLS models using Moran's I statistics (and deeming the models acceptable), (2) applying correction factors for autocorrelation, or (3) accounting for similarities among adjacent area units through 'spatial $\mathrm{lag}^{\prime}$ - the aggregation of nearby census tracts in a separate model. ${ }^{7,17,30}$ Moran's statistic tests for independence among model residuals and can range from -1 (perfect spatial dispersion) to 1 (complete correlation between neighbors). Moran's must also carry an insignificant $p$ value $(p>0.05)$ to be assured that model residuals do not represent autocorrelation. Corrective factors and "spatial lag" can be applied in ArcGIS software. One corrective factor can involve modeling all incidents spatially as a distance from a common point (e.g., city center) to resolve clustering. Our analysis included evaluation of all models with Moran's statistic, and we applied a corrective factor by calculating the distance of each census tract from 8th St. and Market St. in San Francisco. 


\section{RESULTS}

\section{Individual-level Analysis}

Descriptive characteristics of the 300 incidents are shown in Table 1. One-way ANOVA results for traumas at the individual level showed that mean ISS was significantly higher for those with a positive alcohol screen than those with a negative screen or those who went unscreened (F $(2297)=22.6, \mathrm{p}<0.01$; Table 2). Notably, however, linear regression comparing the relationship between ISS and BAL as continuous variables did not show any positive association $\left(R^{2}=0.01\right)$. Thus, while mean ISS was highest among those with a positive screen, it did not trend upward with higher BAL values. The association between ISS and screening also held for drug use ( $\mathrm{F}(2,297)=6.7, \mathrm{p}<0.01)$, although only the difference between those with a positive screen and those unscreened was significant. Injury severity score did not vary significantly with age, type of trauma, or time of day. When accounting for patient mortality, higher ISS did predict longer hospital stays, as would be expected.

Analysis of variance tests showed no significant difference in mean BAL among patient subgroups, including patients of different ages or types of trauma. There was a trend toward increasing BAL among time bins, with the highest mean alcohol level in the "late-night" group (8 pm-6 am); however, this trend did not achieve statistical significance ( $p=0.286$; Table 2$)$. Higher BAL on admission also did not predict longer hospital stays.

\section{Spatial Analysis}

The primary analysis focused on the census tract level to determine spatial variation in trauma density. Trauma and alcohol data were overlaid on San Francisco census tracts in ArcGIS to allow for spatial aggregation and analysis (Graph 1). The number of trauma incidents within a census tract ranged from 0 to 12 , while the number of on-sale and off-sale AOs ranged from 0 to 133 and 0 to 24, respectively. These data were normalized on a per-capita basis within each tract to account for population density (Graph 2). Socioeconomic variables also showed significant variation across the urban environment (Table 3). Ordinary least squares regressions were subsequently performed comparing the independent variable (trauma density) with dependent variables at the census tract level. On-sale and off-sale outlet density showed significant collinearity, so outlet types were modeled separately.

The results of OLS regressions were initially promising (Table 4). Density of off-sale alcohol outlets within a census tract was the strongest correlated variable with density of all traumas $\left(\mathrm{R}_{\mathrm{t}}^{2}=0.52, \mathrm{p}<0.01\right)$. This association held for unintentional trauma $\left(\mathrm{R}_{\mathrm{t}}^{2}=0.51\right.$, $\mathrm{p}<0.01)$ and traumas for which BAL was elevated on
Table 1: Descriptive characteristics of 300 traumas from JanuaryApril 2013. Only traumas for which an EMT run-sheet documented the incident address were included $(n=300)$

\begin{tabular}{ll}
\hline Patient characteristics & $\begin{array}{l}\text { Frequency } \\
\text { (proportion) }\end{array}$ \\
\hline Age (years) & \\
$<18$ & $11(3.6 \%)$ \\
$18-25$ & $43(14 \%)$ \\
$26-40$ & $94(31 \%)$ \\
$41-65$ & $90(30 \%)$ \\
$>65$ & $62(21 \%)$ \\
Time of day (first vitals) & \\
6 am-2 pm & \\
2 pm-8 pm & $62(21 \%)$ \\
8 pm-6 am & $81(27 \%)$ \\
Not recorded & $96(32 \%)$ \\
BAL & $61(20 \%)$ \\
Drawn (pos) & \\
Drawn (neg) & $41(14 \%)$ \\
Not done & $29(10 \%)$ \\
Drug use & $230(77 \%)$ \\
$\quad$ Drawn (pos) & \\
Drawn (neg) & $16(5.3 \%)$ \\
Not done & $19(6.3 \%)$ \\
Type of trauma & $265(88 \%)$ \\
Violent & \\
Intentional (suicide + violence) & \\
Unintentional & $61(20 \%)$ \\
Injury severity score (mean, range) & $65(22 \%)$ \\
Mospital length of stay (days) (mean, range) & $5.3(1-60)$ \\
\hline & $7.8 \%$ \\
\hline
\end{tabular}

${ }^{*}$ Category definitions based on prior reports ${ }^{3,4}$

admission $\left(\mathrm{R}_{\mathrm{t}}^{2}=0.74, \mathrm{p}<0.01\right)$. Violent trauma showed the strongest association with on-sale AO per capita $\left(\mathrm{R}_{\mathrm{vt}}{ }^{2}=0.17, \mathrm{p}<0.01\right)$. When evaluated independently, none of the socioeconomic variables had significant influence

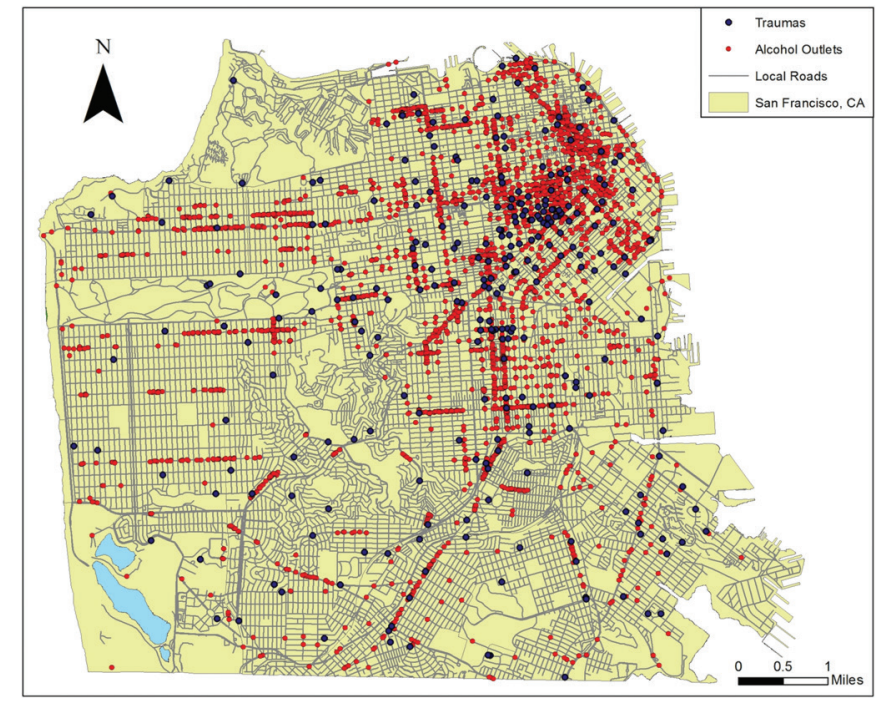

Graph 1: Map of San Francisco, California showing a sample of 300 traumas from January-April 2013 (blue) and all on-sale and off-sale alcohol outlets (red) 
Table 2: One-way ANOVA comparisons for both ISS and BAL within subgroups of traumas Injure severity score vs alcohol use indicator

\begin{tabular}{llllll}
\hline Sources of variance & Degrees of freedom & Sums of squares & Mean squares & F-statistic & $p$-value \\
\hline Alcohol use indicator & 2 & 3334 & 1667.1 & 22.56 & $<0.0001$ \\
Residuals & 297 & 21949 & 73.9 & & \\
\hline Total & 299 & 25283 & & & \\
\hline
\end{tabular}

\begin{tabular}{lll}
\hline Table of Means & Injury severity score (mean) & 95\% confidence intervals \\
\hline Grand mean $(\mathrm{n}=300)$ & 7.08 & \\
Alcohol use indicator & & \\
$\quad$ Positive $(\mathrm{n}=41)$ & 15.07 & \\
Negative $(\mathrm{n}=29)$ & 8.86 & \\
Not measured $(\mathrm{n}=230)$ & 5.43 & $1.9-11.12^{* * *}$ \\
Difference between means & & $6.2-13.1^{* * *}$ \\
Positive - negative & 6.21 & $-0.56-7.42$ \\
Positive - not measured & 9.64 & \\
Negative - not measured & 3.42 & \\
\hline
\end{tabular}

$* * *$ significant at the 0.05 level

Injury severity score vs drug use indicator

\begin{tabular}{llllll}
\hline Sources of variance & Degrees of freedom & Sums of squares & Mean squares & F-statistic & $p$-value \\
\hline Drug use indicator & 2 & 1086 & 542.9 & 6.664 & 0.0015 \\
Residuals & 297 & 24197 & 81.5 & & \\
\hline Total & 299 & 25283 & & & \\
\hline
\end{tabular}

\begin{tabular}{lll}
\hline Table of means & Injury severity score (mean) & 95\% confidence intervals \\
\hline Grand mean $(\mathrm{n}=300)$ & 7.08 & \\
& & \\
Drug use indicator & 13.88 & \\
Positive $(\mathrm{n}=16)$ & 10.58 & \\
Negative $(\mathrm{n}=19)$ & 6.42 & $-3.92-10.5$ \\
Not measured $(\mathrm{n}=265)$ & & $1.98-12.93^{* * *}$ \\
Difference between means & 3.30 & $-0.89-9.20$ \\
Positive - negative & 7.45 & \\
Positive - not measured & 4.16 & \\
Negative - not measured & &
\end{tabular}

*** $=$ significant at the 0.05 level

Blood alcohol level vs time of day

\begin{tabular}{llllll}
\hline Sources of variance & Degrees of freedom & Sums of squares & Mean squares & F-statistic & $p$-value \\
\hline Time of day & 2 & 46058 & 23029 & 1.275 & 0.286 \\
Residuals & 67 & 1210018 & 18060 & & \\
\hline Total & 69 & 1256076 & & & \\
\hline
\end{tabular}

\begin{tabular}{lll}
\hline Table of means & BAL (mean) & 95\% confidence intervals \\
\hline Grand mean $(\mathrm{n}=70)$ & 128.2 & \\
Time of day & & \\
6 am-2 pm $(\mathrm{n}=8)$ & 78.2 & \\
$2 \mathrm{pm}-8 \mathrm{pm}(\mathrm{n}=21)$ & 107.5 & \\
8 pm-6 am $(\mathrm{n}=41)$ & 148.6 & $-45.3-127.57$ \\
Difference between means & & $-54.14-194.86$ \\
$\quad$ Late - afternoon & 41.13 & $-104.6-163.06$ \\
$\quad$ Late - morning & 70.36 & \\
Afternoon - morning & 29.23 & \\
\hline
\end{tabular}




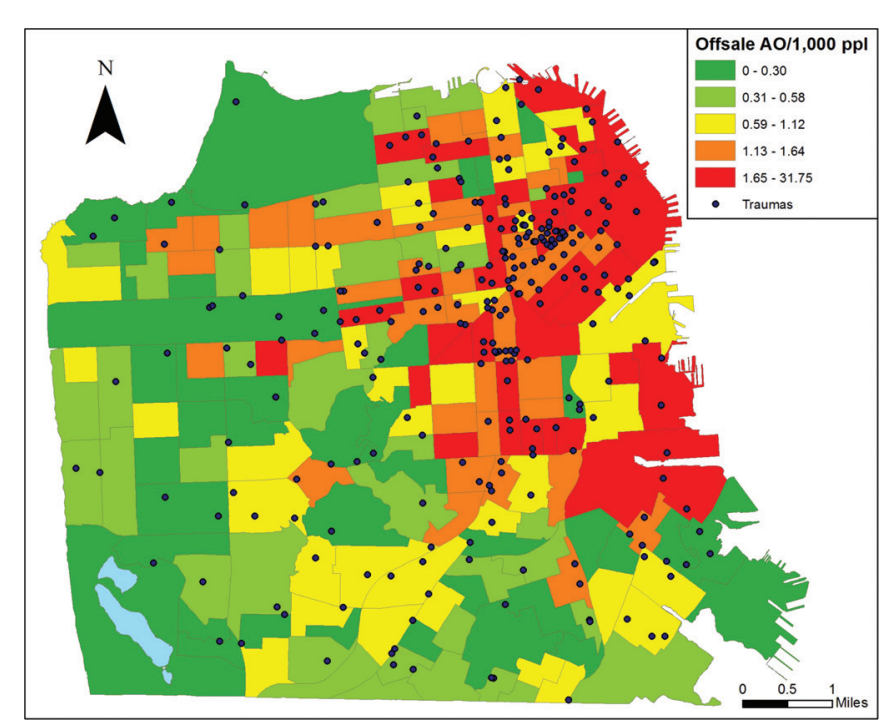

Graph 2: Pilot traumas $(n=300)$ overlaid on census tracts showing off-sale alcohol outlet density per capita. Ordinary least squares regression yields $R^{2}=0.52$ for the relationship between off-sale outlets and trauma density, although significant spatial autocorrelation limits validity of the model

Table 3: Alcohol outlet and socioeconomic data contained within San Francisco County census tracts, based on data from the California ABC and U.S. Census ACS 2009-2013 ( $n=195$ census tracts)

\begin{tabular}{ll}
\hline Census tract variables & Range \\
\hline Alcohol outlets & \\
Total $(\mathrm{N}=3661)$ & $0-157$ \\
Off-sale $(\mathrm{n}=811)$ & $0-24$ \\
On-sale $(\mathrm{n}=2850)$ & $0-133$ \\
Median income (household) & $\cup \mathrm{S} \$ 12,000-\$ 217,000$ \\
Poverty in the last 12 months (\%) & $0-47.5$ \\
Female-led, single-parent & $0-50$ \\
households $(\%)$ & \\
Non-White population (\%) & $0-94$ \\
Unemployment $(\%)$ & $0-35.5$ \\
\hline
\end{tabular}

on rates of total trauma or the subgroups. These variables were included in the models shown in Table 4 but had essentially no influence on the overall $R^{2}$. Unfortunately, models assessing all types of trauma or violent trauma (model 1 and model 3) did not yield acceptable residuals when assessed for spatial autocorrelation, even with a correction factor (model 4). Moran's statistics were significant $(\mathrm{p}<0.05)$ for these models, meaning that the influence of autocorrelation could not be discounted. Model 2, assessing only traumas for which BAL was positive, did yield an acceptable Moran's statistic.

\section{DISCUSSION}

Overall, this study represents a novel approach to characterizing the relationship between alcohol and trauma by combining established individual-level analysis with spatial modeling. To our knowledge, this work was
Table 4: Ordinary least squares regressions for spatial variables within San Francisco census tracts. Ordinary least squares for all traumas (model 1), traumas with positive BAL (model 2), intentional traumas (model 3), and OLS model 1 with distance variable to correct for autocorrelation (model 4)

\begin{tabular}{|c|c|c|c|c|}
\hline Variable & $\begin{array}{l}\text { Model } 1 \\
\text { (all trauma) }\end{array}$ & $\begin{array}{l}\text { Model } 2 \\
\text { (BAL- } \\
\text { positive } \\
\text { trauma) }\end{array}$ & $\begin{array}{l}\text { Model } 3 \\
\text { (violent } \\
\text { trauma) }\end{array}$ & $\begin{array}{l}\text { Model } 4 \\
\text { (all trauma } \\
+ \text { distance } \\
\text { correction) }\end{array}$ \\
\hline Off-sale outlets & $0.2764^{* * *}$ & $0.0868^{* * *}$ & & $0.2738^{* * *}$ \\
\hline On-sale outlets & & & $0.0124^{* * *}$ & \\
\hline $\begin{array}{l}\text { Median } \\
\text { income (\$) }\end{array}$ & 0.0000 & 0.0000 & 0.0000 & 0.0000 \\
\hline Poverty (\%) & -0.0070 & -0.0003 & -0.0010 & -0.0074 \\
\hline $\begin{array}{l}\text { Female-headed } \\
\text { households (\%) }\end{array}$ & -0.0595 & 0.0419 & 0.0847 & 0.0856 \\
\hline $\begin{array}{l}\text { Non-White } \\
\text { population (\%) }\end{array}$ & -0.3890 & -0.0957 & -0.0003 & -0.3736 \\
\hline $\begin{array}{l}\text { Unemployment } \\
(\%)\end{array}$ & 0.0072 & 0.0020 & -0.0007 & 0.0069 \\
\hline $\begin{array}{l}\text { Distance from } \\
\text { city center (ft) }\end{array}$ & & & & -0.000004 \\
\hline $\mathrm{R}^{2}$ & 0.53 & 0.74 & 0.17 & 0.53 \\
\hline $\begin{array}{l}\text { Moran's I } \\
\text { on residuals } \\
\text { ( } p \text {-value) }\end{array}$ & $\begin{array}{c}0.024 \\
(0.016)\end{array}$ & $\begin{array}{c}-0.007 \\
(0.875)\end{array}$ & $\begin{array}{r}0.147 \\
(<0.01)\end{array}$ & $\begin{array}{c}0.020 \\
(0.035)\end{array}$ \\
\hline
\end{tabular}

$* * *=p<0.01$

the first effort to associate mapped trauma incidents with their clinical data (particularly ISS and BAL). In so doing, we believe it is possible to develop a more nuanced understanding of how alcohol availability and consumption plays a role in patient injury. By replacing broad assumptions regarding alcohol consumption (such as time of day or total alcohol purchases) with serum measures and assigning accurate locations of trauma through EMT data, this pilot study represents the most complete effort to date to accurately evaluate the impact of the urban alcohol environment.

Our findings that ISS was higher among those screened for alcohol use (and highest among those with a positive screen) differ from those of Madan et al and Porter. It is notable, however, that ISS did not demonstrate a positive association with BAL as a continuous variable. This result has two likely explanations: First, the overwhelmingly higher ISS with a positive screen may indicate that any amount of alcohol consumption increases risk of severe injury. Second, physician's choices to screen for alcohol were likely influenced by the severity of injury, leading to significant bias among those who were screened. The rate of BAL measurements for 900and 911-level traumas during this pilot study was found to be $23 \%$ (the trauma types were not distinguished in the pilot analysis). With the implementation of universal BAL screening for 900-level traumas in 2013, the measurement rate has since increased significantly, reaching $75 \%$ for 900-level incidents (and 50\% overall) in 2014 and 80\% 
compliance thus far in 2015. The improved enforcement of the BAL screening policy for all 900-level traumas at San Francisco General Hospital should mitigate much of this effect in subsequent data gathering. For those who were screened, mean BAL also did not vary among type of trauma or age group, as was expected given previous work linking alcohol availability to unintentional and intentional trauma among various age groups. 3,16,18-20

The trend for increasing BAL during late-night hours (8 pm-6 am) was not significant, reinforcing the importance of a direct measure of alcohol use among trauma victims. Gruenewald and Ponicki and Livingston considered motor vehicle crashes or assaults in their respective studies to be alcohol related if they occurred after $8 \mathrm{pm}$, while our findings suggest a possible trend, it is clear that such a proxy is not adequate to determine the involvement of alcohol in trauma. The ability of our study to associate BAL with injured patients represents a more thorough approach.

With regard to spatial analysis, it was clear that the density of alcohol availability drove nearly all of the explanatory power in our models. However, our 300 data points in a densely populated, heterogeneous urban environment were not sufficient to overcome effects of spatial autocorrelation. The Moran's statistics for models evaluating all traumas or violent traumas did not pass an acceptable significance threshold, and, while a model for BAL-positive traumas did so, it is difficult to draw strong conclusions from a subset if the overall trauma data is significantly autocorrelated. A corrective distance factor made only a slight improvement (Moran's p value increased from 0.016 to 0.035 , suggesting slightly less autocorrelation). Gruenewald and Remer, Johnson et al, and Gruenewald et al found lower levels of spatial autocorrelation in their analyses, but these studies assigned traumatic injuries to a patient's zip code of residence, rather than the zip code in which a trauma occurred (given that they did not have access to prehospital location in discharge records). These assignments may have had the effect of dispersing traumas more evenly among residential areas, which may not have an impact in a state-level analysis but would certainly overlook the tendency for residents of an urban environment to cluster in popular bar and restaurant areas. We believe that our methodology of assigning accurate trauma locations based on ambulance data is more robust, but our results clearly indicate the need for a large-scale study to address these autocorrelation challenges.

Given ample evidence that alcohol use plays a role in traumatic injury, state and municipal governments have taken steps to limit the proliferation of alcohol establishments and address cofactors contributing to trauma. Such efforts have included limiting the number of days on which alcohol can be sold by off-sale outlets, limiting the number of alcohol vendors by increasing the barrier to obtaining or maintaining a liquor license, or addressing outlet density through zoning law changes. ${ }^{31-33}$ $\mathrm{Xu}$ et al suggest that policy changes in New Orleans, Louisiana have been effective, demonstrating that the positive association between outlet density and assault decreased significantly following the implementation of higher license fees and more alcohol board oversight. However, these policies continue to be based on incomplete data, relying on either spatial analysis laden with assumptions or individual-level data without a geographic component. We believe that our more accurate characterization of the role of alcohol in traumatic injury may allow for more nuanced assessment of public health policy measures.

\section{Study Limitations}

In addition to the challenges of spatial autocorrelation, this pilot study had a number of limitations. Collecting trauma incident locations required ambulance run sheets to be present in paper charts. These run sheets were inconsistently present and charts were not always available for review, leading to the 1,000 incident requests for only 300 data points. Being limited to those traumas for which a run sheet is present could introduce bias into the trauma sample results. Additionally, the inconsistency of BAL screens yielded an even smaller sample size for our subgroup analyses. This small sample of BAL screens was directly related to clinician bias and the inclusion of 911-level traumas for which screening is not required. Future data collection will focus on 900-level traumas with the assumption that mandated serum screenings will greatly reduce this source of bias. Our results regarding a positive relationship between ISS and alcohol screening merit repeat analysis with a larger data set, particularly given that they differed from previous study findings. Overall, although this pilot based on clinical patient data and accurate EMT trauma locations demonstrated a much more thorough analysis approach, adequate data collection is critical. Much of the modeling shortcomings, particularly with regard to autocorrelation, stemmed from having an insufficient number of traumas throughout San Francisco's 195 census tracts. Zhu et al successfully resolved autocorrelation issues by applying a lagged correction in which adjoining census tracts were aggregated to account for spatial similarities, but we did not attempt lagging with this size of data set. Lagged modeling and other attempts at corrective factors would be appropriate given a larger sample of traumas.

This pilot study demonstrated the feasibility of combining individual clinical data with spatial analysis in an effort to more accurately characterize urban trauma. Future analysis can employ a larger data set that will allow for true hierarchical modeling, in which individual 
and aggregated characteristics can be analyzed simultaneously at the census tract level. Increased sampling alone may not resolve these autocorrelation issues, but a significantly higher $\mathrm{N}$ value will allow us to more definitively evaluate this challenge. A hierarchical approach may also yield even more robust explanatory power and could provide more nuanced tools for policy-makers and clinicians in the effort to limit alcohol-related injury.

\section{REFERENCES}

1. Rivara FP, Grossman DC, Cummings P. Injury prevention. First of two parts. N Engl J Med 1997 Aug 21;337(8):543-548.

2. Borges G, Mondragón L, Medina-Mora ME, Orozco R, Zambrano J, Cherpitel C. A case-control study of alcohol and substance use disorders as risk factors for non-fatal injury. Alcohol Alcohol. 2005 Jul-Aug;40(4):257-262.

3. Gruenewald PJ, Ponicki WR. The relationship of the retail availability of alcohol and alcohol sales to alcohol-related traffic crashes. Accid Anal Prev 1995 Apr;27(2):249-259.

4. Livingston M. Alcohol outlet density and assault: a spatial analysis. Addiction 2008 Apr;103(4):619-628.

5. Johnson FW, Gruenewald PH, Remer LG. Suicide and alcohol: do outlets play a role? Alcohol Clin Exp Res 2009 Dec;33(12):2124-2133.

6. Scribner RA, MacKinnon DP, Dwyer JH. The risk of assaultive violence and alcohol availability in Los Angeles County. Am J Public Health 1995 Mar;85(3):335-340.

7. Gorman DM, Speer PW, Gruenewald PJ, Labouvie EW. Spatial dynamics of alcohol availability, neighborhood structure and violent crime. J Stud Alcohol 2001 Sep;62(5):628-636.

8. Gruenewald PJ. Changes in outlet densities affect violence rates. Alcohol Clin Exp Res 2006 Jul;30(7):1184-1193.

9. Toomey TL, Erickson DJ, Carlin BP, Lenk KM, Quick HS, Jones AM, Harwood EM. The association between density of alcohol establishments and violent crime within urban neighborhoods. Alcohol Clin Exp Res 2012 Aug;36(8): 1468-1473.

10. Scribner R, Cohen D, Kaplan S, Allen SH. Alcohol availability and homicide in New Orleans: conceptual considerations for small area analysis of the effect of alcohol outlet density. J Stud Alcohol 1999 May;60(3):310-316.

11. Gorman DM, Zhu L, Horel S. Drug 'hot-spots', alcohol availability and violence. Drug Alcohol Rev 2005 Nov;24(6): 507-513.

12. Yu Q, Li B, Scribner RA. Hierarchical additive modeling of nonlinear association with spatial correlations-an application to relate alcohol outlet density and neighborhood assault rates. Stat Med 2009 Jun 30;28(14):1896-1912.

13. Franklin FA, Laveist TA, Webster DW, Pan WK. Alcohol outlets and violent crime in washington D.C. West J Emerg Med 2010 Aug;11(3):283-290.

14. Mair C, Gruenewald PJ, Ponicki WR, Remer L. Varying impacts of alcohol outlet densities on violent assaults: Explaining differences across neighborhoods. J Stud Alcohol Drugs 2013 Jan;74(1):50-58.
15. Livingston $\mathrm{M}$. A longitudinal analysis of alcohol outlet density and domestic violence. Addiction 2011 May;106(5):919-925.

16. Gruenewald PJ, Freisthler B, Remer L, Lascala EA, Treno AJ, Ponicki WR. Ecological associations of alcohol outlets with underage and young adult injuries. Alcohol Clin Exp Res 2010 Mar 1;34(3):519-527.

17. Grubesic TH, Pridemore WA, Williams DA, Philip-Tabb L. Alcohol outlet density and violence: the role of risky retailers and alcohol-related expenditures. Alcohol Alcohol 2013 SepOct;48(5):613-619.

18. Madan AK, Yu K, Beech DJ. Alcohol and drug use in victims of life-threatening trauma. J Trauma 1999 Sep;47(3):568-571.

19. Porter RS. Alcohol and injury in adolescents. Pediatr Emerg Care. 2000 Oct;16(5):316-20.

20. Savola O, Niemela O, Hillbom M. Alcohol intake and the pattern of trauma in young adults and working aged people admitted after trauma. Alcohol Alcohol 2005 Jul-Aug;40(4):269-273.

21. Watt K, Purdie DM, Roche AM, McClure RJ. The relationship between acute alcohol consumption and consequent injury type. Alcohol Alcohol 2005 Jul-Aug;40(4):263-268.

22. Goldstick JE, Brenner AB, Lipton RI, Mistry R, Aiyer SM, Reischl TM, Zimmerman MA. A Spatial Analysis of Heterogeneity in the Link Between Alcohol Outlets and Assault Victimization: Differences Across Victim Subpopulations. Violence Vict 2015;30(4):649-662.

23. San Francisco Board of Supervisors. 'Regulating Deemed Approved Off-Sale Alcohol Uses and Establishing An Annual Fee'. [cited 2007 Aug 20]

24. Environmental Systems Research Institute. ArcGIS Desktop: Release 9.3.1 (2009). Redlands, CA: ESRI.

25. California Alcoholic Beverage Control. [cited 2013 Mar 4]. Available from: http://www.abc.ca.gov/datport/AHCounty ZIP.asp

26. San Francisco Enterprise GIS. [cited 2013 Mar 4]. Available from: https://data.sfgov.org/

27. United States Census Bureau. [cited 2013 Mar 4] Available from: https://factfinder2.census.gov

28. SAS release 9.4 (2013). Cary, NC: SAS Institute.

29. R Development Core Team. R: A language and environment for statistical computing (2012). Vienna, Austria: R Foundation for Statistical Computing. https://R-project.org

30. Zhu L, Gorman DM, Horel S. Alcohol outlet density and violence: a geospatial analysis. Alcohol Alcohol 2004 JulAug;39(4):369-375.

31. Middleton JC, Hahn RA, Kuzara JL, Elder R, Brewer R, Chattopadhyay S, Fielding J, Naimi TS, Toomey T, Lawrence B; Task Force on Community Preventive Services. Effectiveness of policies maintaining or restricting days of alcohol sales on excessive alcohol consumption and related harms. Am J Prev Med 2010 Dec;39(6):575-589.

32. Xu Y, Yu Q, Scribner R, Theall K, Scribner S, Simonsen N. Multilevel spatiotemporal change-point models for evaluating the effect of an alcohol outlet control policy on changes in neighborhood assaultive violence rates. Spat Spatiotemporal Epidemiol 2012 Jun;3(2):121-128.

33. WBAL. 'City Planning Commission approves liquor store zoning change'. [cited 2013 Mar 22]. 


\section{La influencia de la venta de alcohol en Trauma urbana: Un estudio piloto para Geoespacial Modelado a escala fina}

Este manuscrito presenta una investigación experimental para examinar las relaciones transversales entre las medidas de las características de trauma (por ejemplo, la gravedad de la lesión y BAC) tomadas a nivel individual y ubicaciones de los puntos de venta de alcohol y eventos de una lesión traumática en el tracto de nivel de censo (espacial). El estudio no demuestra "influencias", como lo sugiere el título, pero las asociaciones, y no es un análisis estadístico multinivel sino, más bien, dos diferentes análisis estadísticos de los datos de niveles múltiples. Como estudio piloto es adecuado. Pero los datos y los análisis están limitados en varios aspectos importantes.

Comentarios específicos:

- El resumen informa una medida de R-cuadrado de algún tipo, pero no está claro si se trata de un parcial R-cuadrado o algo más. Por favor, aclarar y utilizar la nomenclatura estadística estándar.

- La introducción está muy bien escrita y argumentada, e interesante. Ha habido un par de publicación anteriores a partir de datos de EMT que vienen a la mente; Banerjee et al (2008), en un capítulo de un libro que es difícil de obtener, y Liang y Chikritzhs (2011) creo que es otra. Estos análisis son poco frecuentes, pero se han hecho.

- En "fuentes de datos" se desprende que alrededor del 66\% de los traumatismos de una ambulancia no fue enviado o una hoja de ejecución no fue proporcionada. Por favor, proporcione los porcentajes para cada uno y hacer comentarios sobre el posible impacto de todos estos datos faltantes en los análisis presentados.

- En una línea similar se desprende que la mayoría de los casos fueron probados para BAL o pruebas de drogas. Esto parece ser una limitación importante en estos datos, sobre todo porque los artefactos de selección son probables.

- Modelos de regresión lineal y análisis de variación no son adecuados para el análisis de datos censurados (censuradas en cero, no hay valores negativos). Esto no es un gran problema para los análisis a nivel individual, ya sea como algunos transformar o enfoque alternativo podrían adoptarse. Sin embargo, estas alternativas deben explorarse debido a que los modelos de análisis también serían más eficientes.

- No está claro cómo ArcGIS proporciona un análisis espacial; no estoy al tanto de este procedimiento. Tal vez lo hace, pero no está claro qué "retardo espacial" se está incorporando en el análisis. Por favor, aclarar. Tampoco está claro cómo la distancia entre el 8 y el Mercado San ST. en San Francisco es un factor de corrección. Por favor explique.

- Vale la pena señalar en este punto que Modelos Durbin "espacial" y procedimientos de análisis espacial relacionados están disponibles en STATA (y probablemente otros paquetes estadísticos) y relativamente fácil de usar (aunque nunca tan fácil como OLS). Estos permiten a los controles directos de autocorrelación espacial utilizando procedimientos estándar.

- En ausencia del uso de los procedimientos de análisis señalar solo y en presencia de grandes tasas de error que Moran Coeficientes tipo puede ser bastante extrema. Esto significa que los resultados presentados son, por tres de los cuatro modelos de análisis, estadísticamente sesgados.

Puedo hacer dos recomendaciones sobre este manuscrito, la diferencia entre ellos está determinada por los objetivos de su publicación en este caso: En primer lugar, si el objetivo es publicar bien escrito hacia el futuro, pero los bits bastante imperfecto de trabajo que son verdaderamente "pilotos" entonces, con algunas revisiones, iba a encontrar esto aceptable; los autores están haciendo todos los esfuerzos en esta área. En segundo lugar, según los estándares de la literatura publicada ampliamente este trabajo no aguanta el escrutinio; que la opinión se debe a que los métodos estadísticos son profundamente defectuoso y la mayoría de los investigadores en este punto se trata con éxito los problemas técnicos que se presentan con los modelos espaciales de varios niveles.

Paul Gruenewald 


\section{The Influence of Alcohol Outlets on Urban Trauma: A Pilot Study for Geospatial Modeling at a Fine Scale}

This manuscript presents pilot research examining cross-sectional relationships between measures of trauma characteristics (e.g., injury severity and BAC) taken at the individual level and locations of alcohol outlets and traumatic injury events at the census tract (spatial) level. The study does not demonstrate "influences," as suggested by the title, but associations, and is not a multilevel statistical analysis but, rather, two different statistical analyses of multilevel data. As a pilot study this is suitable. But the data and analyses are limited in several important respects. Specific comments:

1. The abstract reports an R-square measure of some sort but it is unclear whether this is a partial R-square or something else. Please clarify and use standard statistical nomenclature.

2. The introduction is very well written and argued, and interesting. There have been a couple of previous publication using EMT data that come to mind; Banerjee et al (2008), in a book chapter that is hard to obtain, and Liang and Chikritzhs (2011) I believe is another. These analyses are rare, but they have been done.

3. Under "data sources" it appears that some $66 \%$ of traumas an ambulance was not dispatched or a run sheet provided. Please provide the percentages for each and comment on the likely impact of all this missing data on the analyses presented.

4. In a similar vein, it appears that most cases went untested for BAL or drug screened. This appears to be a substantial limitation on these data, especially since selection artifacts are likely.

5. Linear regression models and ANOVA are unsuitable for analyses of censored data (censored at zero, no negative values). This is not a huge problem for the individual level analyses as either some transform or alternative approach could be taken. But these alternatives should be explored because the analysis models would also be more efficient.

6. It is unclear how ArcGIS provides a spatial analysis; I'm not aware of this procedure. Perhaps it does, but it is unclear what "spatial lag" is being incorporated in the analysis. Please clarify. It is also unclear how distance from 8th St. and Market St. in San Francisco is a corrective factor. Please explain.

7. It is worth noting at this point that "Spatial Durbin Models" and related spatial analysis procedures are available in STATA (and probably other statistical packages) and relatively easy to use (though never as easy as OLS). These allow for direct controls for spatial autocorrelation using standard procedures.

8. Absence of use of the analysis procedures just noted and in the presence of large Moran's coefficients type I error rates can be quite extreme. This means that the results presented are, for three out of four analysis models, statistically biased.

I can make two recommendations about this manuscript, the difference between them being determined by the objectives of your publication in this case: First, if the objective is to publish well written forward looking but somewhat flawed bits of work that are truly "pilots," then, with some revisions, I would find this acceptable; the authors are making every effort in this area. Second, by the standards of the broadly published literature this work would not survive scrutiny; that opinion arises because the statistical methods are deeply flawed and most researchers at this point are successfully dealing with the technical problems that arise with multilevel spatial models.

Paul Gruenewald 